\title{
Chapter 25 \\ Self-Incompatibility System of Ipomoea trifida, a Wild-Type Sweet Potato
}

\author{
Tohru Tsuchiya
}

\begin{abstract}
Diploid Ipomoea trifida (Convolvulaceae) is a close relative of the cultivated hexaploid Ipomoea batatas, the cultivated sweet potato. These plants have sporophytic self-incompatibility that is regulated by a single multiallelic locus, designated as the $S$-locus. Genetic analyses of I. trifida plants collected from Central America identified about 50 different $S$-haplotypes with a linear dominance hierarchy having some codominance relationships. A linkage map of DNA markers around the $S$-locus indicated that the $S$-locus is delimited to $0.23 \mathrm{cM}$. Within the $S$-locus genomic region, a hypervariable genomic region of 35-95 kbp was identified, and we designated this region SDR ( $S$-locus-specific divergent region). Of the several genes located within the SDR, one anther-specific gene, $A B 2$, and three stigma-specific genes, $S E 1, S E 2$, and $S E A$, are candidate $S$-genes that may encode male and female $S$-determinants of self-incompatibility.
\end{abstract}

Keywords Ipomoea trifida $\bullet$ Self-incompatibility $\bullet$ Sweet potato

\subsection{Introduction}

Self-incompatibility (SI) is a genetic mechanism to prevent self-fertilization (and thus encourage outcrossing) in angiosperms. In self-incompatible plants, when a pollen grain is recognized as the same type as self, some stage of pollen germination, pollen tube elongation, ovule fertilization, or embryo development is halted, and no seeds are produced. SI is classified into several groups: homomorphic SI, heteromorphic SI, cryptic SI (CSI), and late-acting SI. Heteromorphic SI is classified into two groups: distyly is determined by a single locus, which has two alleles,

\footnotetext{
T. Tsuchiya $(\triangle)$

Division of Plant Functional Genomics, Life Science Research Center, Mie University, 1577, Kurima-Machiya, Tsu, Mie 514-8507, Japan

e-mail: tsuchiya@gene.mie-u.ac.jp
} 
and tristyly is determined by two loci, each with two alleles. Heteromorphic SI is sporophytic, in that both alleles in the male plant determine the SI response in the pollen. CSI exists in a limited number of taxa (for example, there is evidence for CSI in Silene vulgaris in the Caryophyllaceae; Glaettli 2004). In this mechanism, the simultaneous presence of cross- and self-pollen on the same stigma results in higher seed set from cross-pollen (Bateman 1956). Late-acting SI is also termed ovarian SI. In this mechanism, self-pollen germinates and reaches the ovules, but no fruit is set (Seavey and Bawa 1986; Sage et al. 1994).

Homomorphic SI is classified into sporophytic SI (SSI) and gametophytic SI (GSI) . The SSI system is found in species of several plant families, such as the Brassicaceae, Asteraceae, Malvaceae, Betulaceae, Sterculiaceae, Polemoniaceae, and Convolvulaceae (de Nettancourt 2001; Allen and Hiscock 2008). In the plants in these families, SI is genetically regulated by a single multi-allelic locus, the $S$-locus. Within the $S$-locus, a pair of genes (named $S$-genes), one encoding the male-determinant molecules and the other the female-determinant molecules, is localized. These genes are essential for the SI reaction, because these gene products contribute to self/non-self recognition. The sets of $S$-genes are tightly linked at the $S$-locus, and the $S$-locus (also called $S$-haplotype: Nasrallah and Nasrallah 1993), is inherited as a single unit to maintain the SI system. In the SSI system, self-pollen rejection is observed as the arrest of pollen germination, or pollen tube penetration into the stigma cell, and therefore self/non-self recognition occurs on the surface of the stigma. The male $S$-gene is sporophytically expressed in the tapetum of the anther, and the product of the male $S$-gene ( $S$-protein) is deposited onto the pollen surface. The male phenotype of the SSI plant is determined by the diploid $S$-haplotypes of the pollen-producing plant; therefore, determination of the male $S$-phenotype is under the control of dominant-recessive relationships. On the other hand, the female $S$-gene is expressed in the papilla cells of the stigma. SSI of the Brassicaceae is well characterized at the molecular level; SP11/SCR and SRK are the male and female $S$-genes, respectively. SP11/SCR acts as a ligand of the membraneanchored protein kinase SRK; these two determinants interact when self-pollination occurs, which induces a phosphorylation pathway and inhibits self-pollen germination.

The GSI system is found in the Solanaceae, Rosaceae, Fabaceae, Papavaraceae, and Poaceae, and in most cases it is regulated by a single $S$-locus, except in the Poaceae, which has both $S$ - and Z-loci. In $S$-RNase-mediated GSI, the female $S$-determinant, $S$-RNase, is taken up into the elongating pollen tube and degrades RNA molecules that are recognized as self. In the Papavaraceae, the female $S$-determinant, PrsS, acts as a ligand of the pollen tube membrane-anchored receptor/channel male $S$-determinant, PrpS. After recognition of the pollen grain as self, the $\mathrm{Ca}^{2+}$ concentration in the pollen tube is increased, and actin is depolymerized, resulting in programmed cell death.

Ipomoea trifida is a close relative of the cultivated sweet potato Ipomoea batatas. Self-incompatible plants of the genus Ipomoea show SSI; however, this SI is strong, and is active even in hexaploid species, such as I. batatas (Fig. 25.1). Moreover, the SSI of Ipomoea may be regulated by a different mechanism than SSI in Brassica. In this chapter, this unique SSI system of I. trifida is described. 
Fig. 25.1 Flowers of diploid Ipomoea trifida. Floral structures of plants in the Convolvulaceae are similar to each other, with funnelshaped, radially symmetrical corolla, five sepals, five fused petals, and five epipetalous stamens. The flowering of this plant is enhanced under short-day conditions with relatively high temperature

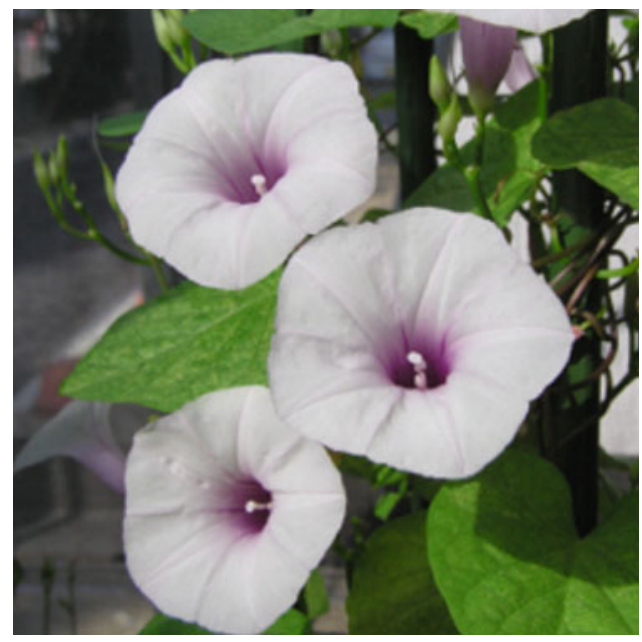

\subsection{Origin, Domestication, and Compatibility of Ipomoea Plants}

Cultivated sweet potato, I. batatas, and its wild relatives belong to the section Batatas. The center of the origin and domestication of the sweet potato is thought to be either in Central America or South America. In Central America, domestication of the sweet potato might have started at least 5,000 years ago, and in South America, Peruvian sweet potato remnants dating as far back as $8000 \mathrm{BC}$ have been found. Austin (1988) postulated that the center of origin of I. batatas was between the Yucatán Peninsula of Mexico and the mouth of the Orinoco River in Venezuela. Zhang et al. (1998) provided strong supporting evidence that the geographic zone postulated by Austin is the primary center of diversity. The much lower molecular diversity found in Peru and Ecuador suggests this region should be considered a secondary center of sweet potato diversity. The sweet potato was also grown in Polynesia. Sweet potato was cultivated in the Cook Islands in $1000 \mathrm{AD}$, and it may have been brought to central Polynesia around 700 AD, and spread across Polynesia to Hawaii and New Zealand from there (van Tilburg 1994; Bassett et al. 2004). A theory that the plant could have spread by seeds floating across the ocean is not supported by evidence. Another point is that the sweet potato in Polynesia is the cultivated I. batatas, which is generally spread by vine cuttings and not by seeds (Fig. 25.2).

Charles Darwin described outcrossing in higher plants and the diversity of reproduction modes (Darwin 1876). He described inbreeding depression based on his experiments with morning glory, Ipomoea purpurea. The family Convolvulaceae contains 55 genera and more than 1,500 species (Austin 1997), and the genus Ipomoea is the largest member of the Convolvulaceae, with more than 500 species. The genus occurs throughout the tropical and subtropical regions of the world, including both annual and perennial herbaceous plants, and most species are twining climbing plants. The floral structure of the genus Ipomoea is almost the same, a 


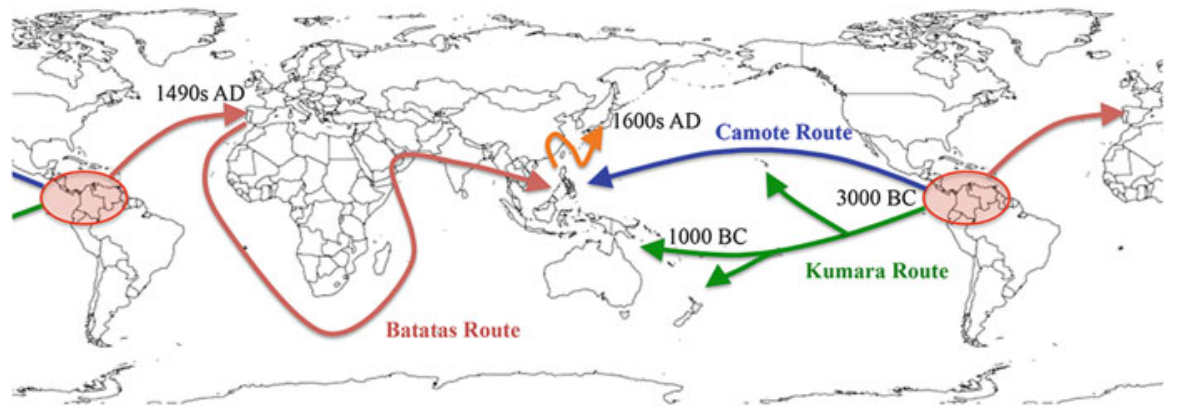

Fig. 25.2 Domestication and distribution of sweet potato. The center of origin and domestication of the sweet potato is thought to be in either Central America or South America. In Central America, sweet potatoes were domesticated at least 5,000 years ago. During the ancient era, sweet potato was thought to be distributed from Central America to the Pacific Islands by two routes, the Camote and the Kumara routes. After Columbus introduced sweet potato to Europe, the sweet potato was distributed to South and Southeast Asian countries, including Japan

gamopetalous flower, resembling that of the morning glory. This genus Ipomoea is classified into several sections based on reproductive and morphological traits (Austin and Huáman 1996). For instance, the section Pharbitis includes both the self-incompatible Ipomoea serifera and the self-compatible species I. purpurea; both horticultural varieties are known as morning glory. This classification is also supported by genetic analysis based on chloroplast DNA restriction site variations (McDonald and Mabry 1992) in section Batatas, which includes sweet potato and its wild relatives, series Pharbitis, which includes Japanese morning glory, and section Tricolor, which includes western morning glory, and others.

About 50 species belong to section Batatas. The site of origin of these plants is considered to be the same region as sweet potato. Plants in the section Batatas can be classified into two groups, one cross-compatible with sweet potato, I. batatas, and the other not. For example, South American species Ipomoea triloba $(2 n=2 x=30)$, Ipomoea tiliacea $(4 x)$, and I. trifida $(2 x, 4 x, 6 x)$ are cross-compatible with I. batatas (6x); however, Ipomoea umbraticola $(2 x)$ is not (Table 25.1). Plants belonging to section Batatas can be alternatively classified as belonging to a selfincompatible (group A) and a self-incompatible (group B) (Table 25.2) (Nishiyama et al. 1975). In group B, the diploid species I. trifida and the tetraploid species Ipomoea tabascana are most closely related to the hexaploid sweet potato I. batatas (Rajapakse et al. 2004). However, according to its chromosome number and SI, I. trifida seems to be the wild species most closely related to I. batatas, and Huang and Sun (2000) revealed that I. trifida is the ancestral species of I. batatas, according to inter-simple sequence repeat and restriction analyses of chloroplast DNA. Artificial hexaploid I. trifida has also been produced (Shiotani and Kawase 1987); currently, it is understood that I. batatas is an autohexaploid of diploid I. trifida, produced by several chromosomal duplication and crossing events (Fig. 25.3) (Shiotani and Kawase 1989). 
Table 25.1 Cross-incompatibility of sweet potato (Ipomoea batatas) with its wild relatives

\begin{tabular}{clll}
\hline & Origin & \\
\cline { 2 - 4 } & North America & South America & Caribbean region \\
\hline Cross-compatible & I. lacunosa $(2 x)$ & & I. triloba $(2 x)$ \\
with I. batatas $(6 x)$ & I. cordatotriloba $(2 x)$ & & I. tiliacea $(4 x)$ \\
& & I. trifida $(2 x, 4 x, 6 x)$ \\
Cross-incompatible & I. tenuissima $(2 x)$ & I. ramosissima $(2 x)$ & I. umbraticola $(2 x)$ \\
with $I$. batatas $(6 x)$ & & I. grandifolia $(2 x)$ & \\
\hline
\end{tabular}

The wild population of plants that belong to section Batatas are classified into two major groups, one cross-compatible with cultivated sweet potato, and the other cross-incompatible. I. trifida, the close relative to cultivated sweet potato, is cross-compatible with sweet potato, despite the varied ploidy level

Table 25.2 Classification of several species of Ipomoea in section Batatas according to their self-incompatibility

\begin{tabular}{lll}
\hline & Scientific name & Chromosome numbers \\
\hline Group A: self-compatible & I. lacunosa & $2 n=30$ \\
& I. cordatotriloba & $2 n=30$ \\
& I. tenuissima & $2 n=30$ \\
& I. triloba & $2 n=30$ \\
& I. ramosissima & $2 n=30$ \\
& I. cynanchifolia & $2 n=30$ \\
Group B: self-incompatible & I. perviana & $2 n=30$ \\
& I. gracilis & $2 n=30$ \\
& I. tiliacea & $2 n=60$ \\
& I. trifida & $2 n=30,60,90$ \\
& I. batatas & $2 n=90$ \\
\hline
\end{tabular}

Plants belonging to section Batatas are also classified under their mode of reproduction: selfcompatibility (group A) and self-incompatibility (group B)

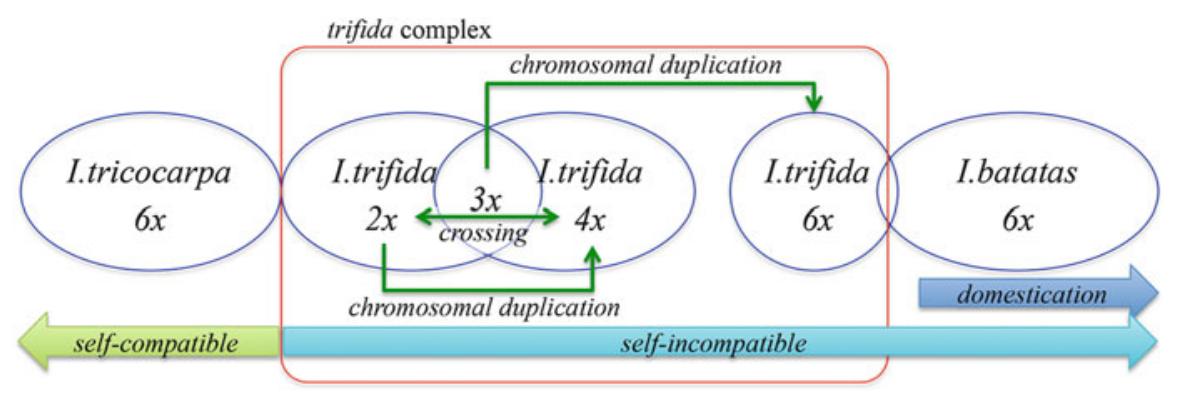

Fig. 25.3 Establishment of Ipomoea batatas from Ipomoea trifida. I. batatas $(2 n=6 x=90)$ is thought to be an autohexaploid of diploid I. trifida. Hexaploid I. trifida was produced through two chromosomal duplications and crossing in the wild population, and the resulting plant became the ancestral species of $I$. batatas, the cultivated sweet potato. During these stages, self-incompatibility did not break down. However, once self-incompatibility was broken down, the reproduction mode was not resumed, and a self-compatible species was established 
In the practical breeding of sweet potato, cross-incompatibility between parental plants is a genetic barrier to producing hybrids because the choice of parents for cross-pollination is sometimes limited to a small number of lines. I. trifida, a diploid species of the section Batatas, is a useful genetic resource in sweet potato breeding (Shiotani and Kawase 1987). I. trifida is an herbaceous insect-pollinated weed native to Central America and has a relatively small genome (532 Mbp, $831 \mathrm{Mbp}$ per haploid) (Arumuganathan and Earle 1991; Ozias-Akins and Jarret 1994).

\subsection{SI of Ipomoea Plants}

Compatible cross-pollinating pollen grains germinate about 10-20 min after pollination (Kowyama et al. 2008), with pollen grains attaching to stigma surface cells called papilla cells (Fig. 25.4). However, in the case of incompatible self-pollination, pollen germination is arrested, not resulting in seed formation. In the SI system of I. trifida, the self-recognition reaction between male and female $S$-determinants ( $S$-gene products) occurs rapidly after pollination. Kowyama et al. $(1980,1994)$ reported that the SI phenotype of I. trifida segregates as a single multi-allelic $S$-locus, and the pollen phenotype of SI is regulated sporophytically with clear dominant-recessive relationships between $S$-haplotypes. These features are consistent with the general features of SSI. In Brassica, $\mathrm{CO}_{2}$ treatment and bud pollination can permit self-pollination (Hinata et al. 1994); however, these artificial techniques are not applicable in Ipomoea. From this point of view, it is conceivable that the SSI mechanism of Ipomoea is stronger and clearer than in Brassica plants.
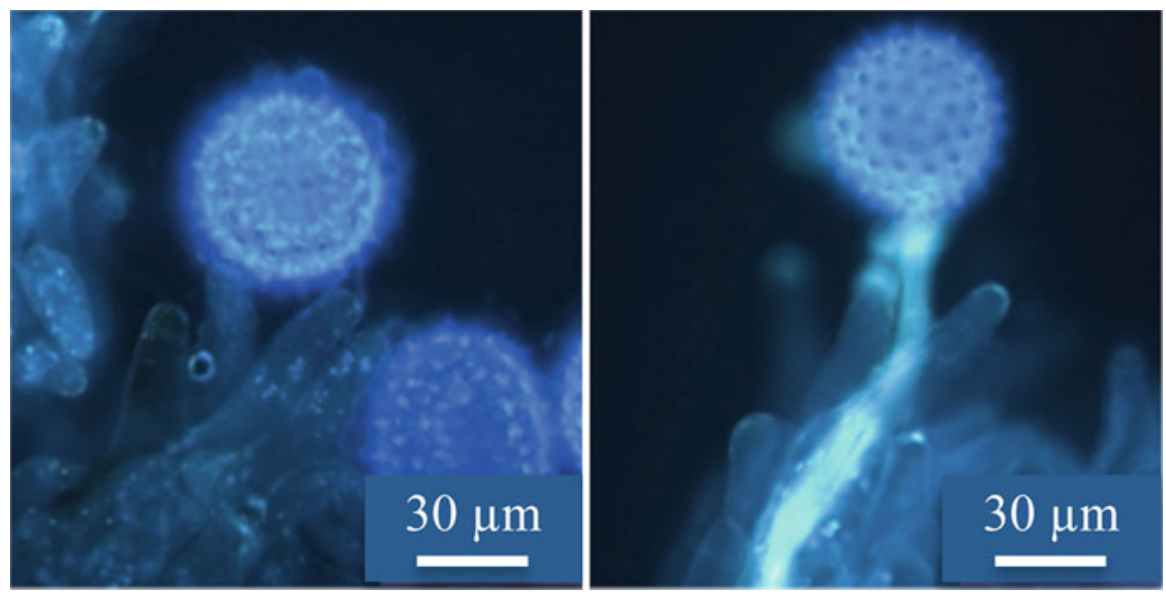

Fig. 25.4 Pollen behavior during self- and cross-pollination of $I$. trifida. Pollen tube germination is completely arrested during self-pollination (left), including crossing between plants with the same $S$-phenotype; however, pollen tube germination is not inhibited during cross-pollination (right) 


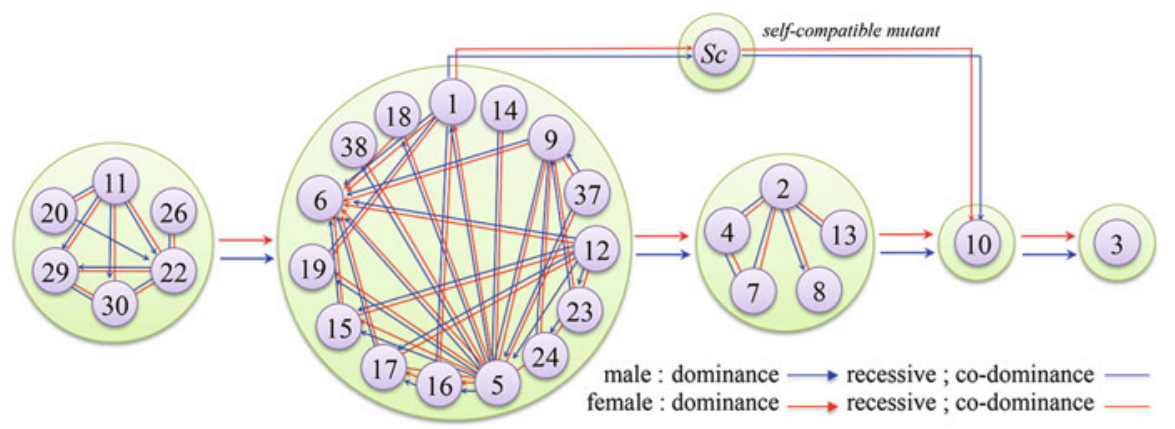

Fig. 25.5 Dominant-recessive hierarchy among 28 self-incompatible and 1 self-compatible mutant of I. trifida. Twenty-eight $S$-haplotypes are classified into five linear dominant-recessive groups. In each group, dominant-recessive relationships are slightly different between $S$-haplotypes in male and female reproductive organs. Arrows are drawn from dominant to recessive; lines indicate codominant relationships. The original $S$-haplotype of the self-compatible $(\mathrm{Sc}$ ) allele is unknown; however, $S c$ is recessive to the $S_{I}$ haplotype and dominant over the $S_{10}$ haplotype. (Figure is redrawn from Kowyama et al. 2008)

Kowyama et al. (1994) identified 49 different $S$-haplotypes from 224 individuals collected from six natural populations in Central America. S-haplotypes of I. trifida showed a linear dominant-recessive hierarchy between $S$-alleles and could be placed into five classes (Fig. 25.5). The $S$-alleles belonging to each class are the same for the male and female sides of the interaction (Fig. 25.5); however, several pairs of $S$-alleles show different interactions on the male and female sides. For example, $S_{22}$ and $S_{29}$ are codominant on the female side (stigma), and $S_{22}$ is dominant over $S_{29}$ on the male side (pollen). The linear hierarchy of dominant-recessive relationships suggests that new dominant $S$-haplotypes were created over recessive $S$-haplotypes, and the variation in allelic interaction suggests that the genetic mechanism for determination of the dominant-recessive hierarchy is regulated in different ways on the male and female sides.

In surveys for self-compatible ( $\mathrm{Sc}$ ) mutants to understand the genetic mechanism underlying SI in I. trifida, only one self-compatible plant (MX1) has been found as a spontaneous mutant from a natural population in Central America; its $S$-haplotype is designated $S c$ (Kakeda et al. 2000). Genetic analysis of the $F_{1}$ progeny derived from crosses between MX1 and several $S$-homozygous plants indicated that the $S c$ allele is also within the dominant-recessive hierarchy; $S c$ is recessive to $S_{I}$ and dominant over $S_{10}$ (Kakeda et al. 2000). The original $S$-allele is unknown; however, the fact that the $S c$ haplotype is within the dominant-recessive hierarchy suggests that $S c$ lacks one or more genes that contribute to SI but maintains genes that contribute to determination of dominance among $S$-haplotypes. Analyses of $S c$ mutants have provided important information for understanding the genetic features of SI in Brassica (Watanabe et al. 1997), Pyrus (Sassa et al. 1997), Solanum (Royo et al. 1994), and other plant species. In the case of Ipomoea, analyzing the $S c$ mutant may provide information to allow elucidation of the genetic features of SI. 


\subsection{Several Approaches to Identifying $S$-Genes in I. trifida}

Because I. trifida has SSI, the $S$-genes have to meet several conditions. Male and female $S$-genes have to be expressed in the tapetum of the anther and papilla cells of the stigma, respectively, and these $S$-genes have to be linked tightly to maintain the $S$-haplotype at the $S$-locus. Moreover, these $S$-genes have to be present in a single copy per genome, and $S$-genes have to be polymorphic between $S$-haplotypes. In initial studies of gene products correlating with SI of I. trifida, reproductive organspecific genes and genes similar to $S$-genes of other plant species were surveyed. Ipomoea stigma protein 11 (ISP11) has been isolated from a mature stigma cDNA library; however, this gene cannot be an $S$-gene, because it is expressed not only in stigma but also in the anther, and it is not linked to the $S$-locus, although it is a single-copy gene (Kowyama et al. 1995b). Because I. trifida has the same genetic SI system as Brassica species, it might be expected that products of genes homologous to $S L G$ or $S R K$ would be present in the reproductive tissues of I. trifida. SRK is known as a female $S$-gene (Stein et al. 1991; Takasaki et al. 2000), and $S L G$ is an $S$-gene-related gene in Brassica (Kandasamy et al. 1989). Ipomoea secreted glycoprotein genes (ISG1, -2, and -3) were isolated from a mature stigma cDNA library, and the sequences of these genes showed structural similarities to Brassica SLGs. However, these genes were not linked to the $S$-locus of $I$. trifida, and these cDNAs have been considered truncated derivatives or modified genes of membraneanchored protein kinase genes that are expressed predominantly in various vegetative tissues of I. trifida (Kowyama et al. 1995a; Kakeda and Kowyama 1996), similar to the SLR3 gene in Brassica oleracea (Cock et al. 1995). Ipomoea receptor kinase 1 (IRKI) was isolated as a gene homologous to SRK in Brassica, and its predicted amino-acid sequence was more similar to that of SRK6 (Stein et al. 1996) in Brassica, ARK1 (Tobias et al. 1992) in Arabidopsis than to ZmPK1 (Walker and Zhang 1990) in Zea mays. However, both the pattern of gene expression and the results of RFLP analysis indicate that the IRKI gene does not have any major involvement in the SI system of Ipomoea (Kowyama et al. 1996).

In initial studies of the gene products associated with SI, an $S$-locus glycoprotein (SLG) in Brassica (Nishio and Hinata 1977; Nasrallah et al. 1985) and an S-locus ribonuclease (S-RNase) in Nicotiana (Anderson et al. 1986) were identified as pistil proteins that co-segregate with $S$-haplotypes. SLG and $S$-RNase are major proteins that are expressed abundantly in the pistil and are detectable by protein electrophoresis of tissue extracts. Currently, the functional role of SLG is somewhat controversial, because some functional $S$-haplotypes of Brassica rapa lack the SLG gene (Suzuki et al. 2003). Because these pioneering studies stimulated molecular studies on SI in many plant species, a similar approach was attempted with Ipomoea. After two-dimensional polyacrylamide gel electrophoresis (2D-PAGE) of proteins extracted from mature stigmas of $I$. trifida, one highly polymorphic protein spot was detected (Kowyama et al. 2000). This protein is about $70 \mathrm{kDa}$, with a pI of 4-6. The protein spots were associated with $S$-haplotypes, so we designated them $S$-locuslinked stigma proteins (SSPs). The SSP gene encodes a short-chain alcohol dehydrogenase family protein, and this gene is expressed abundantly in mature papilla 
cells of the stigma. However, the amino-acid sequence of the SSPs from several $S$-haplotypes showed more than $95 \%$ identity, and the SSP gene is located about $1.1 \mathrm{cM}$ from the $S$-locus of I. trifida (Tomita et al. 2004a). Our surveys of 2D-PAGE profiles from stigma and pollen extracts have so far identified no $S$-haplotypespecific proteins other than SSP, which suggests that the $S$-locus gene products of I. trifida are minor proteins that might be present in amounts too small to be detectable by standard 2D-PAGE analysis.

\subsection{Isolating and Analyzing the $S$-Locus in I. trifida}

Fine-scale mapping of a gene locus is necessary to start positional cloning to identify a gene of interest. To obtain DNA markers, AFLP (amplified fragment length polymorphism: Vos et al. 1995) and AMF (AFLP-based mRNA fingerprinting: Money et al. 1996) methods are useful to identify molecular markers that are tightly linked to or co-segregate with a genetic trait (Agrama et al. 2002; Simoes-Araujo et al. 2002). These methods were attempted in I. trifida for identification of DNA markers around the $S$-locus with DNA and cDNA from 10 to 15 plants for each of the four $S$ genotypes in the $\mathrm{F}_{1}$ progeny from a single cross of $S_{1} S_{22} \times S_{10} S_{29}$. Based on the AFLP and AMF analyses, eight DNA markers were linked to the $S$-locus, and three were mapped closely to the $S$-locus (SAM-23, AAM-68, and AF-41; Fig. 25.6: Tomita et al. 2004a). The SAM-23 marker, derived from the stigma AMF analysis, contains a partial sequence of the SSP gene. The AAM-68 marker was obtained from the anther AMF analysis, and is tightly linked to the $S$-locus, with no recombinants among $873 \mathrm{~F}_{1}$ plants. The AAM-68 marker is a partial sequence of a glycosyltransferase family member and is expressed in the anther and pollen; however, the predicted amino-acid sequences of this gene from different $S$-haplotypes exhibit high similarity. This finding suggests that the $A A M-68$ gene is unlikely to be the $S$-gene. One AFLP marker, AF-41, was located on the opposite side of the $S$-locus to SAM-23 at an interval of $0.11 \mathrm{cM}$, and the sequence of AF-41 was similar to that of the histone deacetylase gene of Arabidopsis. Using these DNA markers as probes, BAC, cosmid and lambda phage clones covering the $S$-locus were screened from genomic libraries of the $S_{l}$ haplotype. The terminal sequences of the BAC clones 682-T7 and 681-SP6 map to 0.74 and $0.46 \mathrm{cM}$ from the $S$-locus, respectively.

Up to now, no recombination between male and female determinant genes of SI has been observed in any plant species. If recombination between these two genes occurs, it leads to breakdown of SI. In the case of I. trifida, no recombination between the two components was observed among $873 \mathrm{~F}_{1}$ plants, a result similar to that observed in Brassica (Casselman et al. 2000) and sweet cherry (Ikeda et al. 2005), so the $S$-locus may be located within a region where recombination is suppressed. Analysis of the DNA sequences amplified near the DNA markers among $873 \mathrm{~F}_{1}$ siblings allowed identification and mapping of four recombination breakpoints (Fig. 25.6; Rahman et al. 2007a). According to DNA marker analysis, the $S$-locus of I. trifida is delimited to between 0.23 and $0.57 \mathrm{cM}$. The physical size of the $S$-locus may be estimated at about $212 \mathrm{~kb}$ in the $S_{l}$ haplotype (Kowyama et al. 2008). 


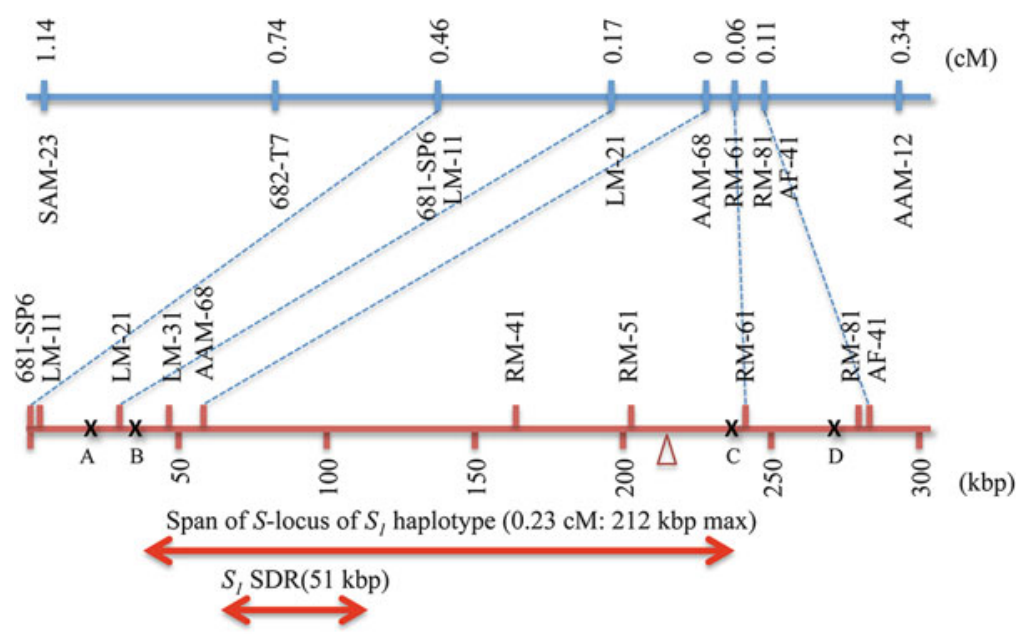

Fig. 25.6 Linkage map around the $S$-locus and location of recombination breakpoints in the $S_{l}$ haplotype. Upper: Linkage map of DNA markers derived from AFLP and AMF analyses and from PCR-amplified fragments. Numbers above the line indicate genetic distances (in cM) from the $S$-locus. Lower: Physical map of the DNA markers and positions of the recombination breakpoints. The numbers below the line indicate physical distance (in kbp). Breakpoints A-D are marked with $X$ s on the map. The physical span of the $S$-locus (about $212 \mathrm{kbp}$ ) was estimated from the distance between breakpoints B and C. The $S$-haplotype-specific divergent region (SDR) was estimated to be about $51 \mathrm{kbp}$ on the basis of sequence comparison between the $S_{1}$ and $S_{10}$ haplotypes. (Figure redrawn from Rahman et al. 2007a)

In the case of Brassica campestris, $S$-locus of the $S_{8}$ haplotype is $70 \mathrm{~kb}$ long (Casselman et al. 2000). Within this region, two recombination breakpoints were identified that are $0.3 \mathrm{cM}$ apart. The relative amount of recombination on the chromosome is calculated by the ratio of DNA length per recombination unit $(\mathrm{kb} / \mathrm{cM})$. A ratio of about $920 \mathrm{~kb} / \mathrm{cM}$ was calculated for the $S$-locus of the $S_{l}$ haplotype (Rahman et al. 2007a). This value is higher than in B. campestris, in which the ratio appears to be $233 \mathrm{~kb} / \mathrm{cM}$ (Casselman et al. 2000), so recombination within the $S$-locus is highly suppressed in I. trifida. In the $S$-locus region of Petunia inflata, the ratio was calculated as $17.6 \mathrm{Mb} / \mathrm{cM}$ because of its centromeric localization (Wang et al. 2003). Fluorescence in situ hybridization analysis of metaphase chromosomes in I. trifida indicated that the $S$-locus region is localized at the distal end of a chromosome (Suzuki et al. 2004). This result supports the idea that suppression of recombination at the $S$-locus of I. trifida is not caused by the location of the locus. Prevention of recombination within the $S$-locus may be regulated because of the necessity of preventing outbreeding through SI. Therefore, the two genes that encode recognition molecules for SI have to be located within a delimited $S$-locus, SP11/SCR [S-locus protein 11/S-locus cysteine (Cys)-rich protein] and SRK ( $S$-receptor kinase) for Brassica plants, and two unidentified genes for I. trifida. The suppression of recombination around the $S$-locus might contribute to the maintenance of the gene complex as a single genetic unit. 


\subsection{S-Locus of I. trifida}

The structure of the $S$-locus has been analyzed in several plant species by genomic sequencing. These analyses provide evidence to determine male- and femaledeterminant genes at the $S$-locus that contribute to the self/non-self recognition in SI, and to polymorphism between $S$-haplotypes among these genes. $S$-determinant genes ( $S$-genes) of the SSI system in Brassica species, SP11/SCR and SRK, show polymorphism between $S$-haplotypes (Sherman-Broyles and Nasrallah 2008). To determine the genomic sequence of the S-locus region of I. trifida, sequence contigs of about $300 \mathrm{kbp}$ were constructed by map-based cloning using BAC, cosmid, and lambda libraries from $S_{1}$ homozygotes (Tomita et al. 2004b), and $68 \mathrm{kbp}$ from $S_{10}$ homozygotes (Rahman et al. 2007a). Comparison of the $S_{1}$ and $S_{10} S$-locus regions revealed high variability in the $S$-locus region, which was designated the $S$-haplotypespecific divergent region (SDR; Fig. 25.7). The length of the SDR is about $50 \mathrm{kbp}$ in the $S_{10}$ haplotype, $35 \mathrm{kbp}$ in the $S_{I}$ haplotype, and about $95 \mathrm{kbp}$ in the $S_{29}$ haplotype. The flanking region of the SDR is highly conserved between $S$-haplotypes. In other self-incompatible plant species, a highly divergent region has been identified. In Brassica species, highly divergent regions from 30 to $56 \mathrm{kbp}$ are present in the $S$-locus region, and this region is flanked by sequences with high similarity (Fukai et al. 2003; Shiba et al. 2003). This polymorphic region is also observed in Prunus

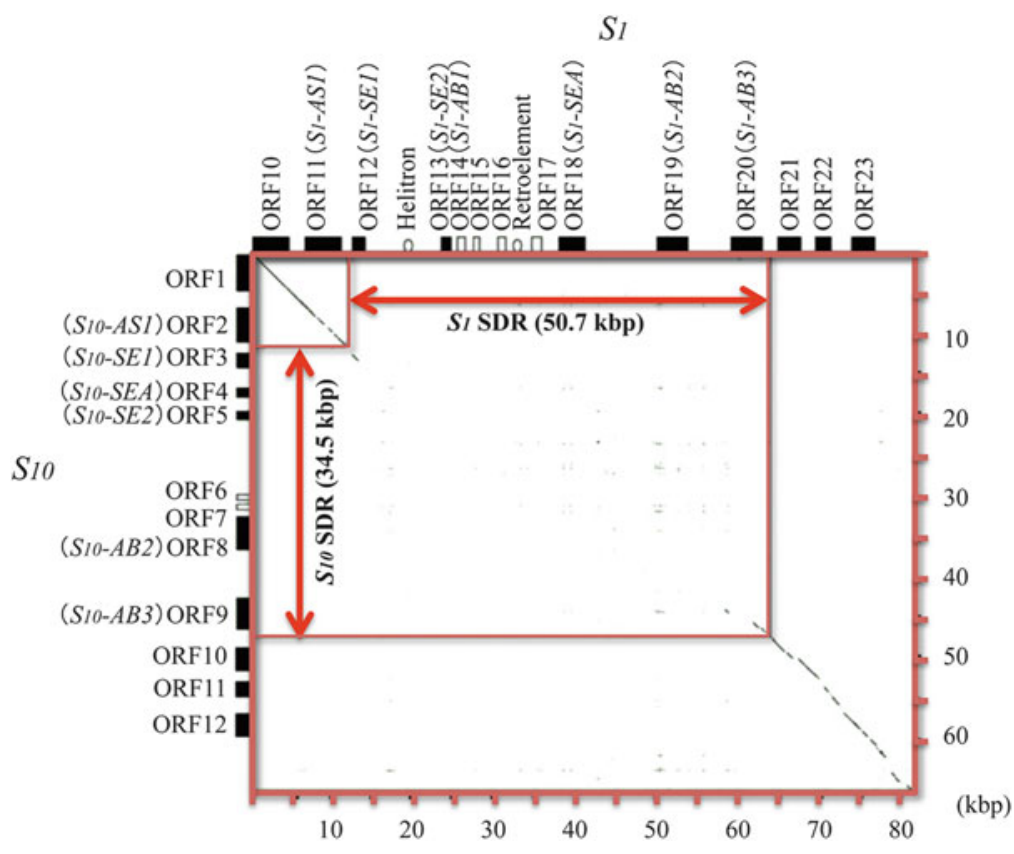

Fig. 25.7 Comparison of the nucleotide sequences spanning the $S$ loci of the $S_{l}$ and $S_{10}$ haplotypes by ARR plot analysis. Highly polymorphic regions are shown as SDRs. Estimated sizes of the SDRs are 50.7 and $34.5 \mathrm{kbp}$ for the $S_{l}$ and $S_{10}$ haplotypes, respectively. (Figure from Rahman et al. 2007a) 
and Malus (Ushijima et al. 2001; Entani et al. 2003; Sassa et al. 2007). In these plants, male- and female-determinant genes involved in SI are located within these polymorphic regions in the $S$-locus region. Therefore, the $S$-determinant genes of I. trifida may be located in the SDR of the $S$-locus region.

The size differences in the SDR of I. trifida among S-haplotypes may be caused by the insertion of transposon-like sequences, retroelement-like sequences, and simple sequence repeats that accumulate in the larger SDRs (Rahman et al. 2007a). An interesting correlation between allelic dominance and SDR size has emerged from sequence comparisons of $S$-locus regions: the more dominant the $S$-haplotype, the larger the SDR. This finding suggests that acquisition of sequence complexity by recessive $S$-haplotypes is responsible for the differentiation of more dominant $S$-haplotypes.

\subsection{Genes Located at or Near the $S$-Locus of I. trifida}

Reproductive organ-specific genes at the $S$-locus may be directly correlated with self/non-self recognition in SI, one acting as male and the other as female determinant genes. In $S$-RNase-based GSI, $S$-RNases are abundantly expressed in the transmitting tract of the style, and they directly inhibit the growth of self-pollen tubes (Lee et al. 1994). The pollen determinant genes, SFB/SLF and related genes, are expressed in developing pollen grains and pollen tubes (Ushijima et al. 2003; Entani et al. 2003; Sijacic et al. 2004; Sassa et al. 2007, 2010; Meng et al. 2010; Kakui et al. 2011), and they recognize self or non-self S-RNases (Meng et al. 2010; Sassa et al. 2010). In Papaver plants, the female $S$-gene product, PrsS, is an extracellular signaling molecule that acts as a ligand to the self male $S$-gene product, $\operatorname{PrpS}$, a transmembrane ion-channel/receptor. When self PrsS is recognized by self PrpS, $\mathrm{Ca}^{2+}$ flux is triggered and results in the depolymerization of actin fibers (Geitmann et al. 2000), activating several signaling pathways ( $\mathrm{Li}$ et al. 2007) and inducing programmed cell death through activation of caspase-like activity in the growing pollen tube (Bosch and Franklin-Tong 2007). In the SSI system of Brassica, SLG and $S R K$ genes are expressed in the mature papilla cells of the stigma (Nasrallah and Nasrallah 1993). The expression of $S R K$ is significantly lower than $S L G$; however, $S R K$ plays a key role in the self-pollen recognition of Brassica (Takasaki et al. 2000). The male $S$-gene in Brassica, SP11/SCR, is tightly linked to the $S R K$ gene at the $S$-locus and is expressed in the anther tapetum (the sporophytic tissue) and microspores at a late developmental stage of pollen grains (Schopfer et al. 1999; Takayama et al. 2000; Shiba et al. 2002). According to previous experiments, the $S$-genes are specifically expressed in reproductive organs, and the expression pattern of these two components coincides with the characters and types of SI.

To identify the genes located in the $S$-locus region of I. trifida, Northern blot analyses were carried out with shotgun clones as probes that were used to determine the whole sequence of the $S_{I} S$-locus (Fig. 25.8). More than ten genes were identified in the $S_{1} S$-locus region; however, three stigma-specific (SE1, SE2, and SEA) 


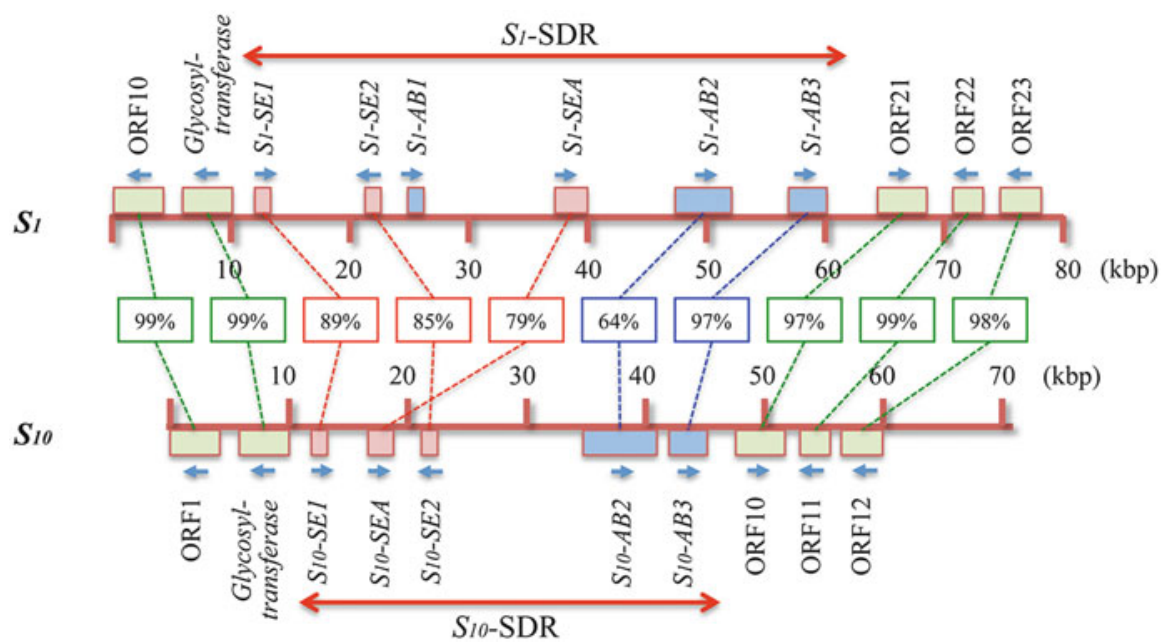

Fig. 25.8 Alignment of $S$-locus genes in the $S_{I}$ and $S_{10}$ haplotypes showing locations of the SDRs in the $S_{I}$ and the $S_{10}$ haplotype. Red boxes indicate stigma-specific genes (SE1, SE2, SEA) and blue boxes anther-specific genes $(A B 1, A B 2, A B 3)$ identified in the SDR. Green boxes indicate open reading frames $(O R F \mathrm{~s})$ outside the SDR. Arrows beside the boxes show orientation of transcription and numbers below each line show physical distances (in kbp). Genes or ORFs in common between the two $S$-haplotypes are connected by dotted lines with percentage nucleotide identity shown in boxes. (Figure redrawn from Rahman et al. 2007a)

and four anther-specific genes $(A B 1, A B 2, A B 3$, and $A B 4)$ were located in the region (Rahman et al. 2007b). All three $S E$ genes and three $A B$ genes $(A B 1-A B 3)$ were located in the SDR of the $S_{I}$ haplotype. Northern blot analyses using total RNA prepared from reproductive organs at several developmental stages and from vegetative organs indicated that all $A B$ genes were expressed in the anthers 1-2 weeks before flowering. During this developmental period, pollen grains are at the microspore stage, and thus the tapetum of the anther is viable, not degraded. All SE genes were expressed in the stigma beginning 1 week before anthesis through the day before flowering. The transcripts of these six genes were not detected in other reproductive organs ( $A B$ genes were not expressed in the stigma, and $S E$ genes were not expressed in the anther) or vegetative organs. According to Southern blot analysis, the $A B 1$ gene is present in at least two copies per genome; however, the other five genes are present as single copies. Therefore, these five genes $(A B 2, A B 3$, and three $S E$ genes) are currently candidate $S$-genes based on their localization in the SDR, expression patterns, and copy number.

Among the anther-specific genes, $S_{1}-A B 1$ showed $95 \%$ similarity to $S_{I}-A B 3$; however, $A B 1$ is not located in the SDR of the $S_{10}$-haplotype. Furthermore, the sequence similarity of $A B 1$ and $A B 3$ genes was more than $95 \%$ between $S$-haplotypes. From these results, $A B 1$ and $A B 3$ are not likely to be involved in the determination of $S$-haplotype specificity on the male side of I. trifida. On the other hand, $A B 2$ is located in the $S$-locus genomic region of all tested $S$-haplotypes, $S_{1}, S_{10}$, and $S_{29}$. 


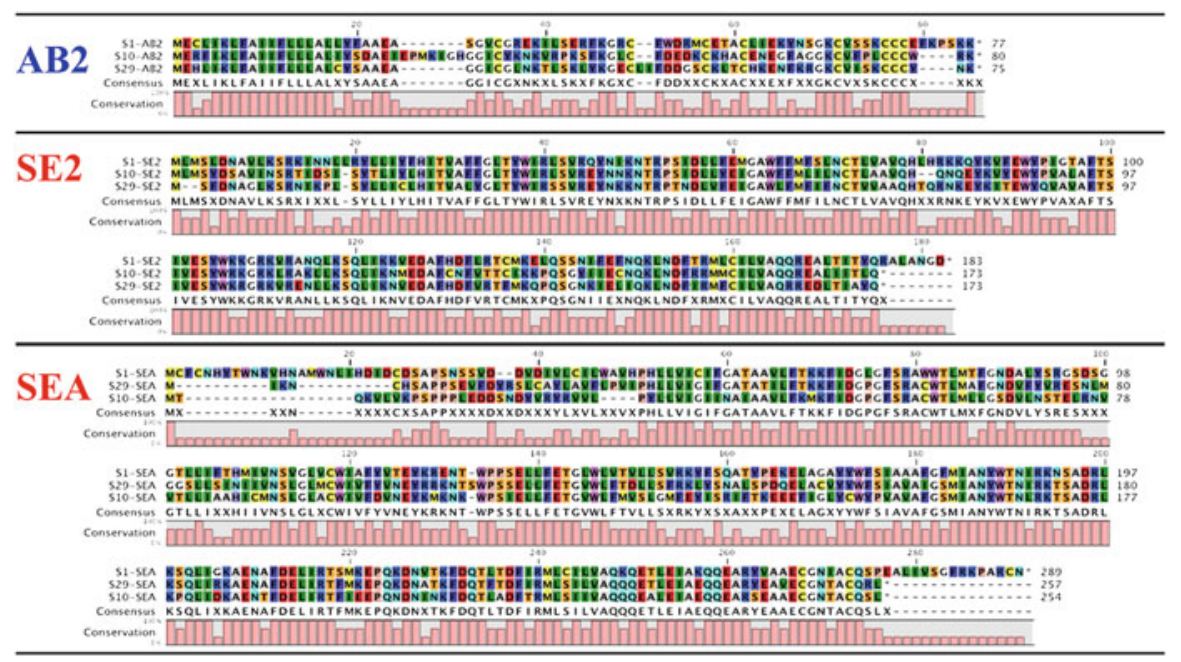

Fig. 25.9 Alignment of amino-acid sequences of $S$-candidates from $S_{1}, S_{10}$, and $S_{29}$ alleles. Similar residues are indicated by the same colors

Sequence comparison of the predicted amino acid sequences of these genes showed 46-58 \% identity between tested $S$-haplotypes (Fig. 25.9). According to temporal and spatial expression analyses, the $A B 2$ gene is only expressed in the tapetum of the anther at 14 to 7 days before anthesis, not in other reproductive organs or vegetative organs. A prediction program for protein structural features suggested that AB2 proteins have extracellular signaling domains at their N-termini that are highly conserved among $S$-haplotypes.

In addition, the predicted AB2 protein sequence shows homology to plant defensins, a class of Cys-rich proteins that are members of the gamma-thionin protein family. The defensins are small peptides (about 100 amino acids or less) with antimicrobial activities and are widely distributed in plants and animals (Boman 2003). Genes for defensin-like proteins such as PCP-A1 (Doughty et al. 1998) and SP11/ SCR (Suzuki et al. 1999; Schopfer et al. 1999) are also expressed in the tapetum of developing Brassica anthers. Amino-acid sequence comparison of Ipomoea AB2 proteins with Brassica SP11/SCR proteins showed that only the eight Cys residues are conserved; however, sequences interlaid between the conserved Cys residues are not conserved in length or amino-acid residues (Fig. 25.10). Because the number of Cys residues is only conserved between AB2 and SP11/SCR, these two proteins may be structurally different. However, the possibility remains that this small AB2 protein acts as male $S$-determinant in the SI of I. trifida. If true, the AB2 protein may act as a ligand for the female $S$-determinant, which may be a receptor-like protein, as in Brassica.

cDNA clones of the stigma-specific genes (the $S E$ genes), also showed a high level of allelic polymorphism among $S$-haplotypes and were located on the SDR of the $S$-locus. The predicted amino-acid sequences of the SE1, SE2, and SEA proteins 


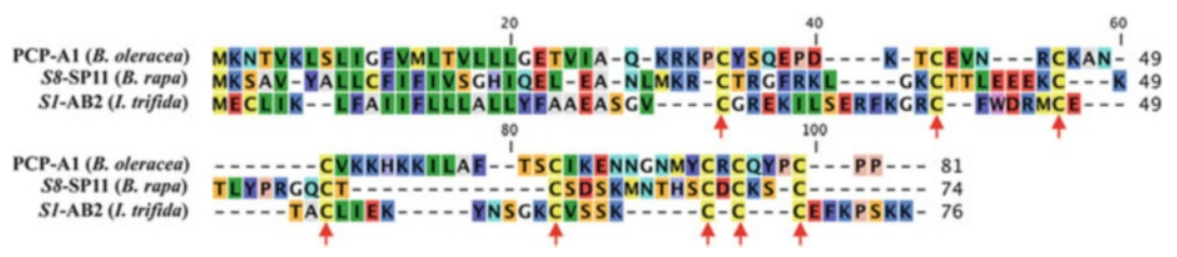

Fig. 25.10 Similarity between AB2 protein sequence and that of other PCP-A1 family proteins. Protein sequences of PCP-A1 from Brassica oleracea and $S_{8}$-SP11/SCR from B. rapa, and the predicted protein sequence of $S_{l}$-AB2 from I. trifida, were aligned. Conserved Cys residues in mature peptides of all three proteins are indicated with arrows
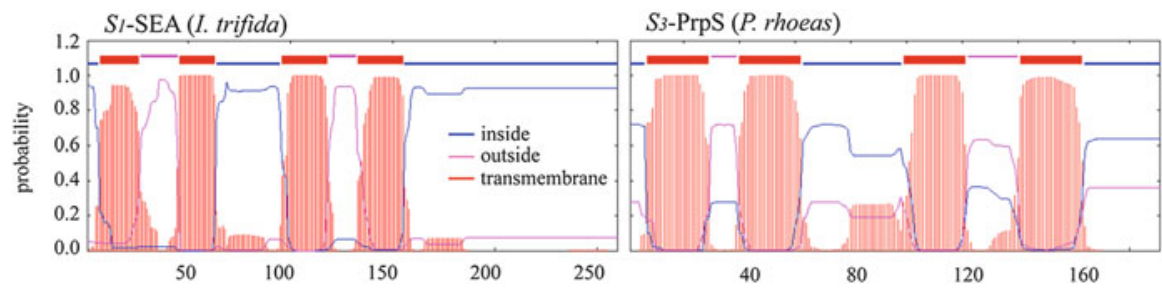

Fig. 25.11 Predicted structures of $S_{I}$-SEA protein of I. trifida and $S_{3}$-PrpS protein of Papaver rhoeas. Female $S$-candidate proteins, SE2 and SEA, of $I$. trifida, and male $S$-protein, PrpS, of $P$. rhoeas are predicted as membrane-anchored proteins with three or four membrane-spanning domains by the TMHMM program (http://www.cbs.dtu.dk/services/TMHMM/). However, these protein sequences showed no significant similarity to other reported proteins

are, respectively, 53-76\%, 67-69\%, and 52-62\% identical among the tested $S$-haplotypes (Fig. 25.9).

Expression analyses indicated that $S E 1, S E 2$, and $S E A$ are expressed in the papilla cells of the stigma at 7 to 1 days before anthesis. The predicted amino-acid sequences of all $S E$ genes showed no similarity to known proteins in the database. However, hydropathy plot analysis indicated that these proteins may share three to four membrane-spanning domains, and may localize to the plasma membrane of papilla cells, where the interaction between pollen and stigma cells occurs. The structural features of SE proteins are similar to the predicted structure of PrpS proteins, the female determinant of SI of Papaver (Wheeler et al. 2009), and the flower protein of Drosophila (Yao et al. 2009; Brose and Neher 2009), which may act as a $\mathrm{Ca}^{2+}$ channel in synaptic endocytosis (Fig. 25.11). In the GSI of Papaver plants, $\mathrm{Ca}^{2+}$ influx into self-pollen tubes is observed, and may regulated by PrpS. If the SE proteins play the same role in the SI of I. trifida, some ion, such as $\mathrm{Ca}^{2+}$, may induce signal transduction to inhibit germination of self-pollen on the stigma surface, as in Papaver plants.

Taken together, the available data suggest that the $S E 1, S E 2$, and $S E A$ genes that are expressed in the papilla cells of the stigma are candidates for the female $S$-determinant genes, and the $A B 2$ gene that is expressed in the tapetum of the 
anther is a strong candidate for the male $S$-determinant gene in the SI of I. trifida. To determine the true $S$-genes of I. trifida, both functional analyses of these genes by creating transgenic plants expressing these genes and molecular-molecular interaction analyses of the gene products may be necessary to obtain definitive evidence. Further study is also necessary to determine an outline of the selfincompatible reaction in I. trifida.

\subsection{Conclusion}

SI of angiosperms is not regulated by a single and simple genetic mechanism. In the GSI system of the Plantaginaceae, Solanaceae, and Rosaceae, S-RNase has been identified as a female determinant and $S F B / S L F$ and related genes as male determinants of recognition specificity. In this system, RNA and protein degradation are involved during pollen tube growth in the style (McClure and Franklin-Tong 2006). In another gametophytic system in the Papavaraceae, PrsS acts as a ligand from the stigma and PrpS as a receptor or channel molecule on the plasma membrane of the pollen tube, and their interaction induces a $\mathrm{Ca}^{2+}$-mediated signaling cascade to induce programmed cell death and inhibit pollen tube growth (Franklin-Tong and Franklin 2003; Thomas and Franklin-Tong 2004; Wheeler et al. 2010). On the other hand, in SSI of the Brassicaceae, SRK acts as receptor kinase on the papilla cells of stigma and SP11/ SCR as its cognate ligand on the pollen grain, resulting in self-pollen tube germination through activation of a phosphorylation pathway of downstream signaling molecules (Kachroo et al. 2002; Takayama and Isogai 2005). In the other plant species with SSI, such as the Convolvulaceae and Asteraceae, SRK-mediated self-recognition has been postulated (Hiscock and McInnis 2003). However, at least in I. trifida of the Convolvulaceae, the SRK-mediated signaling pathway is not recruited.

Interestingly, in the SI system in I. trifida, a candidate molecule for the male determinant, $\mathrm{AB} 2$, is similar to SP11/SCR protein, the male $S$-determinant molecule of Brassica plants with SSI; however, candidate molecules for the female determinant, SE1, SE2, and SEA, resemble PrpS protein, the male $S$-determinant of Papaver plants with GSI. This finding supports the hypothesis that SI systems may have arisen independently in the evolution of angiosperms (Allen and Hiscock 2008). Our research with I. trifida may provide important information about the evolution of the system of SI and may contribute to the breeding of crop plants in the Convolvulaceae, including cultivated sweet potato. The classification of SI into two types, namely GSI and SSI, is based simply on differences in gene expression of pollen determinants, not on the molecular mechanisms that underlie the SI systems in these plant families. Investigation of a wide range of plant taxa is required to understand the evolutionary lineage of the SI systems in flowering plants.

Acknowledgments Our research was supported by a Grant-in-Aid for Scientific Research on Innovative Areas (No. 22112513) and Grants-in-Aid for Scientific Research C (Nos. 18580004, 20580004 and 23580005) from the Ministry of Education, Culture, Sports, Science and Technology, Japan. 
Open Access: This article is distributed under the terms of the Creative Commons Attribution Noncommercial License which permits any noncommercial use, distribution, and reproduction in any medium, provided the original author(s) and source are credited.

\section{References}

Agrama HA, Houssin SF, Tarek MA (2002) Cloning of AFLP markers linked to resistance to Peronosclerospora sorghi in maize. Mol Genet Genomics 267:814-819

Allen AM, Hiscock SJ (2008) Evolution and phylogeny of self-incompatibility systems in angiosperms. In: Franklin-Tong VE (ed) Self-incompatibility in flowering plants: evolution, diversity and mechanisms. Springer, Berlin/Heidelberg, pp 73-101

Anderson MA, Cornish EC, Mau S-L, Williams EG, Hoggart R, Atkinson A, Bonig I, Grego B, Simpson R, Roche PJ, Haley JD, Penschow JD, Niall HD, Tregear GW, Coughlan JP, Crawford RJ, Clarke AE (1986) Cloning of cDNA for a stylar glycoprotein associated with expression of self-incompatibility in Nicotiana alata. Nature (Lond) 321:38-44

Arumuganathan K, Earle ED (1991) Nuclear DNA content of some important plant species. Plant Mol Biol Rep 9:208-218

Austin DF (1988) The taxonomy, evolution and genetic diversity of sweetpotatoes and related wild species. In: Gregory P (ed) Exploration, maintenance, and utilization of sweetpotato genetic resources. CIP, Lima, pp 27-60

Austin DF (1997) Convolvulaceae (morning glory family). http://www.fau/divdept/biology/ people/convolv.htm

Austin DF, Huáman Z (1996) A synopsis of Ipomoea (Convolvulaceae) in the Americas. Taxon 45:3-38

Bassett KN, Gordon HW, Nobes DC, Jacomb C (2004) Gardening at the edge: documenting the limits of tropical Polynesian kumara horticulture in Southern New Zealand. Geoarchaeology 19:185-218

Bateman AJ (1956) Cryptic self-incompatibility in the wallflower: Cheiranthus cheiri L. Heredity 10(2):257-261

Boman HG (2003) Antibacterial peptides: basic facts and emerging concepts. J Intern Med 254:197-215

Bosch M, Franklin-Tong VE (2007) Temporal and spatial activation of caspase-like enzymes induced by self-incompatibility in Papaver pollen. Proc Natl Acad Sci USA 104: $18327-18332$

Brose N, Neher E (2009) Flowers for synaptic endocytosis. Cell 138:836-837

Casselman AL, Vrebalov J, Conner JA, Singhal A, Giovannoni J, Nasrallah ME, Nasrallah JB (2000) Determining the physical limits of Brassica $S$-locus by recombinational analysis. Plant Cell 12:23-33

Cock JM, Stanchev B, Delorme V, Croy RRD, Dumas C (1995) SLR3: a modified receptor kinase gene that has been adapted to encode a putative secreted glycoprotein similar to the $\mathrm{S}$ locus glycoprotein. Mol Gen Genet 248:151-161

Darwin CR (1876) The effects of cross- and self-fertilisation in the vegetable kingdom. Murray, London

de Nettancourt D (2001) Incompatibility and incongruity in wild and cultivated plants. SpringerVerlag Berlin Heidelberg New York

Doughty J, Dixon S, Hiscock SJ, Willis AC, Parkin IAP, Dickinson HG (1998) PCP-A1, a defensinlike Brassica pollen coat protein that binds the $S$-locus glycoprotein, is the product of gametophytic gene expression. Plant Cell 10:1333-1347

Entani T, Iwano M, Shiba H, Che FS, Isogai A, Takayama S (2003) Comparative analysis of the self-incompatibility $S$-locus region of Prunus mume: identification of a pollen-expressed F-box gene with allelic diversity. Genes Cells 8:203-213 
Franklin-Tong VE, Franklin FCH (2003) Gametophytic self-incompatibility inhibits pollen tube growth using different mechanisms. Trends Plant Sci 8:598-605

Fukai E, Fujimoto R, Nishio T (2003) Genomic organization of the $S$ core region and the $S$ flanking regions of a class-II $S$-haplotype in Brassica rapa. Mol Genet Genomics 269:361-369

Geitmann A, Snowman BN, Emons AMC, Franklin-Tong VE (2000) Alterations in the actin cytoskeleton of pollen tubes are induced by the self-incompatibility reaction in Papaver rhoeas. Plant Cell 12:1239-1251

Glaettli M (2004) Mechanisms involved in the maintenance of inbreeding depression in gynodioecious Silene vulgaris (Caryophyllaceae): an experimental investigation. $\mathrm{PhD}$ dissertation, University of Lausanne

Hinata K, Isogai A, Isuzugawa K (1994) Manipulation of sporophytic self-incompatibility in plant breeding. In: Williams EG, Clarke AE, Knox RB (eds) Genetic control of self-incompatibility and reproductive development in flowering plants. Kluwer, Dordrecht, pp 102-115

Hiscock SJ, McInnis S (2003) Pollen recognition and rejection during the sporophytic selfincompatibility response: Brassica and beyond. Trends Plant Sci 8:606-613

Huang JC, Sun M (2000) Genetic diversity and relationships of sweet potato and its wild relatives in Ipomoea series Batatas (Convolvulaceae) as revealed by inter-simple sequence repeat (ISSR) and restriction analysis of chloroplast DNA. Theor Appl Genet 100:1050-1060

Ikeda K, Ushijima K, Yamane H, Tao R, Hauck NR, Sebolt AM, Iezzoni AF (2005) Linkage and physical distances between the $S$-haplotype S-RNase and SFB genes in sweet cherry. Sex Plant Reprod 17:289-296

Kachroo A, Nasrallah ME, Nasrallah JB (2002) Self-incompatibility in the Brassicaceae: receptor-ligand signaling and cell-to-cell communication. Plant Cell 14(suppl):s227-s238

Kakeda K, Kowyama Y (1996) Sequences of Ipomoea trifida cDNAs related to the Brassica $S$-locus genes. Sex Plant Reprod 9:309-310

Kakeda K, Tsukada H, Kowyama Y (2000) A self-compatible mutant $S$ allele conferring a dominant negative effect on the functional $S$ allele in Ipomoea trifida. Sex Plant Reprod 13:119-125

Kakui H, Kato M, Ushijima K, Kitaguchi M, Kato S, Sassa H (2011) Sequence divergence and loss-of-function phenotypes of $S$ locus F-box brothers genes are consistent with non-self recognition by multiple pollen determinants in self-incompatibility of Japanese pear (Pyrus pyrifolia). Plant J 68:1028-1038

Kandasamy MK, Paolillo DJ, Faraday CD, Nasrallah JB, Nasrallah ME (1989) The $S$-locus specific glycoproteins of Brassica accumulate in the cell wall of developing stigma papillae. Dev Biol 134:462-472

Kowyama Y, Shimano N, Kawase T (1980) Genetic analysis of incompatibility in the diploid Ipomoea species closely related to the sweet potato. Theor Appl Genet 58:149-155

Kowyama Y, Takahashi H, Muraoka K, Tani T, Hara K, Shiotani I (1994) Number, frequency and dominance relationships of $S$-alleles in diploid Ipomoea trifida. Heredity 73:275-283

Kowyama Y, Kakeda K, Nakano R, Hattori T (1995a) SLG/SRK-like genes are expressed in the reproductive tissues of Ipomoea trifida. Sex Plant Reprod 8:333-338

Kowyama Y, Morikami A, Furusawa T, Hattori T, Nakamura K (1995b) Molecular characterization of a reproductive organ-specific cDNA clone, ISP11 from Ipomoea trifida. Breed Sci 45:497-501

Kowyama Y, Kakeda K, Kondo K, Imada T, Hattori T (1996) A putative receptor protein kinase gene in Ipomoea trifida. Plant Cell Physiol 37(5):681-685

Kowyama Y, Tsuchiya T, Kakeda K (2000) Sporophytic self-incompatibility in Ipomoea trifida, a close relative of sweet potato. Ann Bot 85(Suppl A):191-196

Kowyama Y, Tsuchiya T, Kakeda K (2008) Molecular genetics of sporophytic self-incompatibility in Ipomoea, a member of the Convolvulaceae. In: Franklin-Tong VE (ed) Self-incompatibility in flowering plants: evolution, diversity and mechanisms. Springer, Berlin/Heidelberg, pp 259-274

Lee H-S, Huang S, Kao T-H (1994) S proteins control rejection of incompatible pollen in Petunia inflata. Nature (Lond) 367:560-563 
Li S, Samaj J, Franklin-Tong VE (2007) A mitogen-activated protein kinase signals to programmed cell death induced by self-incompatibility in Papaver pollen. Plant Physiol 145:236-245

McClure BA, Franklin-Tong V (2006) Gametophytic self-incompatibility: understanding the cellular mechanisms involved in "self" pollen tube inhibition. Planta (Berl) 224:233-245

McDonald JA, Mabry TJ (1992) Phylogenetic systematics of New World Ipomoea (Convolvulaceae) based on chloroplast DNA restriction site variation. Plant Syst Evol 180:243-259

Meng X, Sun P, Kao TH (2010) S-RNase-based self-incompatibility in Petunia inflata. Ann Bot 108:637-646

Money T, Reader R, Qu LJ, Dunford RP, Moore G (1996) AFLP-based mRNA fingerprinting. Nucleic Acids Res 24(13):2616-2617

Nasrallah JB, Nasrallah ME (1993) Pollen-stigma signaling in the sporophytic self-incompatibility response. Plant Cell 5:1325-1335

Nasrallah JB, Kao T-H, Goldberg ML, Nasrallah ME (1985) A cDNA clone encoding an S-locus specific glycoprotein from Brassica oleracea. Nature (Lond) 318:263-267

Nishio T, Hinata K (1977) Analysis of S-specific proteins in stigma of Brassica oleracea L. by isoelectric focusing. Heredity 38:391-396

Nishiyama I, Miyazaki T, Sakamoto S (1975) Evolutionary autoploidy in the sweet potato (Ipomoea batatas (L.) Lam.) and its progenitors. Euphytica 24:197-208

Ozias-Akins P, Jarret RL (1994) Nuclear DNA content and ploidy levels in the genus Ipomoea. J Am Soc Hortic Sci 119:110-115

Rahman MH, Tsuchiya T, Suwabe K, Kohori J, Tomita RN, Kagaya Y, Kobayashi I, Kakeda K, Kowyama Y (2007a) Physical size of the $S$-locus region defined by genetic recombination and genome sequencing in Ipomoea trifida, Convolvulaceae. Sex Plant Reprod 20:63-72

Rahman MH, Uchiyama M, Kuno M, Hirashima N, Suwabe K, Tsuchiya T, Kagaya Y, Kobayashi I, Kakeda K, Kowyama Y (2007b) Expression of stigma- and anther-specific genes located in the $S$-locus region of Ipomoea trifida. Sex Plant Reprod 20:73-85

Rajapakse S, Nilmalgoda SD, Molnar M, Ballard RE, Austin DF, Bohac JR (2004) Phylogenetic relationships of the sweet potato in Ipomoea series Batatas (Convolvulaceae) based on nuclear $\beta$-amylase gene sequences. Mol Phylogenet Evol 30:623-632

Royo J, Kunz C, Kowyama Y, Anderson MA, Clarke AE, Newbigin E (1994) Loss of histidine residue at the active site of $S$-ribonuclease leads to self-compatibility in Lycopersicon peruvianum. Proc Natl Acad Sci USA 91:6511-6514

Sage TL, Bertin RI, Williams EG (1994) Ovarian and other late-acting self-incompatibility systems. In: Williams EG, Knox RB, Clarke AE (eds) Genetic control of self-incompatibility and reproductive development in flowering plants. Kluwer, Amsterdam, pp 116-140

Sassa H, Hirano H, Nishio T, Koba T (1997) Style-specific self-compatible mutation caused by deletion of the S-RNase gene in Japanese pear (Pyrus serotina). Plant J 12:223-227

Sassa H, Kakui H, Miyamoto M, Suzuki Y, Hanada T, Ushijima K, Kusaba M, Hirano H, Koba T (2007) $S$-locus F-box brothers; multiple and pollen-specific F box genes with S-haplotypespecific polymorphisms in apple and Japanese pear. Genetics 175:1869-1881

Sassa H, Kakui H, Minamikawa M (2010) Pollen-expressed F-box gene family and mechanism of $S$-RNase-based gametophytic self-incompatibility (GSI) in Rosaceae. Sex Plant Reprod 23:39-43

Schopfer CR, Nasrallah ME, Nasrallah JB (1999) The male determinant of self-incompatibility in Brassica. Science 286:1697-1700

Seavey SF, Bawa KS (1986) Late-acting self-incompatibility in angiosperms. Bot Rev 52(2): $195-218$

Sherman-Broyles S, Nasrallah JB (2008) Self-incompatibility and evolution of mating systems in the Brassicaceae. In: Franklin-Tong VE (ed) Self-incompatibility in flowering plants: evolution, diversity and mechanisms. Springer, Berlin/Heidelberg, pp 123-147

Shiba H, Iwano M, Entani T, Ishimoto K, Shimosato H, Che F-S, Satta Y, Ito A, Takada Y, Watanabe M, Isogai A, Takayama S (2002) The dominance of alleles controlling selfincompatibility in Brassica pollen is regulated at the RNA level. Plant Cell 14:491-504 
Shiba H, Kenmochi M, Sugihara M, Iwano M, Kawasaki S, Suzuki G, Watanabe M, Isogai A, Takayama S (2003) Genomic organization of the S-locus region of Brassica. Biosci Biotechnol Biochem 67:622-626

Shiotani I, Kawase T (1987) Synthetic hexaploids derived from wild species related to sweet potato. Jpn J Breed 37:367-376

Shiotani I, Kawase T (1989) Genetic structure of the sweet potato and hexaploids in Ipomoea trifida (H.B.K.) Don. Jpn J Breed 39:57-66

Sijacic P, Wang X, Skirpan AL, Wang Y, Dowd PE, McCubbin AG, Huang S, Kao T-H (2004) Identification of the pollen determinant of $S$-RNase-mediated self-incompatibility. Nature (Lond) 429:302-305

Simoes-Araujo JL, Rodrigues RL, de A Gerhardt LB, Mondego JM, Alves-Ferreira M, Rumjanek NG, Margis-Pinheiro (2002) Identification of differentially expressed genes by cDNA-AFLP technique during heat stress in cowpea nodules. FEBS Lett 515:44-50

Stein JC, Dixit R, Nasrallah ME, Nasrallah JB (1996) SRK, the stigma-specific S locus receptor kinase of Brassica, is targeted to the plasma membrane in transgenic tobacco. Plant Cell 8:429-445

Stein JC, Howlett B, Boyes DC, Nasrallah ME, Nasrallah JB (1991) Molecular cloning of a putative receptor protein kinase gene encoded at the self-incompatibility locus of Brassica oleracea. Proc Natl Acad Sci USA 88:8816-8820

Suzuki G, Kai K, Hirose T, Fukui K, Nishio T, Takayama S, Isogai A, Watanabe M, Hinata K (1999) Genomic organization of the $S$-locus: identification and characterization of genes in $S L G / S R K$ region of $S_{9}$ haplotype of Brassica campestris (syn. rapa). Genetics 153:391-400

Suzuki G, Kakizaki T, Takada Y, Shiba H, Takayama S, Isogai A, Watanabe M (2003) The $S$-haplotypes lacking $S L G$ in the genome of Brassica rapa. Plant Cell Rep 21:911-915

Suzuki G, Tanaka S, Yamamoto M, Tomita RN, Kowyama Y, Mukai Y (2004) Visualization of the $S$-locus region in Ipomoea trifida: toward positional cloning of self-incompatibility genes. Chromosome Res 12:475-481

Takasaki T, Hatakeyama K, Suzuki G, Watanabe M, Isogai A, Hinata K (2000) The $S$ receptor kinase determines self-incompatibility in Brassica stigma. Nature (Lond) 403:913-916

Takayama S, Isogai A (2005) Self-incompatibility in plants. Annu Rev Plant Biol 56:467-489

Takayama S, Shiba H, Iwano M, Shimosato H, Che FS, Kai N, Watanabe M, Suzuki G, Hinata K, Isogai A (2000) The pollen determinant of self-incompatibility in Brassica campestris. Proc Natl Acad Sci USA 97:1920-1925

Thomas SG, Franklin-Tong VE (2004) Self-incompatibility triggers programmed cell death in Papaver pollen. Nature (Lond) 429:305-309

Tobias CM, Howlett B, Nasrallah JB (1992) An Arabidopsis thaliana gene with sequence similarity to the $S$-locus receptor kinase of Brassica oleracea. Plant Physiol 99:284-290

Tomita RN, Fukami K, Takayama S, Kowyama Y (2004a) Genetic mapping of AFLP/AMFderived DNA markers in the vicinity of the self incompatibility locus in Ipomoea trifida. Sex Plant Reprod 16:265-272

Tomita RN, Suzuki G, Yoshida K, Yano Y, Tsuchiya T, Kakeda K, Mukai Y, Kowyama Y (2004b) Molecular characterization of a 313-kb genomic region containing the self-incompatibility locus of Ipomoea trifida, a diploid relatives of sweet potato. Breed Sci 54:165-175

Ushijima K, Sassa H, Tamura M, Kusaba M, Tao R, Gradziel TM, Dandekar AM, Hirano H (2001) Characterization of the $S$-locus region of almond (Prunus dulcis): analysis of a somaclonal mutant and a cosmid contig for an $S$-haplotype. Genetics 158:379-386

Ushijima K, Sassa H, Dandekar AM, Gradziel TM, Tao R, Hirano H (2003) Structural and transcriptional analysis of the self-incompatibility locus of almond: identification of a pollenexpressed F-box gene with haplotype-specific polymorphism. Plant Cell 15:771-781

van Tilburg JA (1994) Easter Island: archaeology, ecology and culture. Smithsonian Institution Press, Washington, DC

Vos P, Hogers R, Bleeker M, Reijans M, van de Lee T, Hornes M, Friters A, Pot J, Paleman J, Kuiper M, Zabeau M (1995) AFLP: a new technique for DNA fingerprinting. Nucleic Acids Res 23(21):4407-4414 
Walker JC, Zhang R (1990) Relationship of a putative receptor protein kinase from maize to the $S$-locus glycoproteins of Brassica. Nature (Lond) 345:743-746

Wang Y, Wang X, McCubbin AG, Kao T-H (2003) Genetic mapping and molecular characterization of the self-incompatibility S-locus in Petunia inflata. Plant Mol Biol 53:565-580

Watanabe M, Ono T, Hatakeyama K, Takayama S, Isogai A, Hinata K (1997) Molecular characterization of $S L G$ and $S$-related genes in a self-compatible Brassica campestris L. var. yellow sarson. Sex Plant Reprod 10:332-340

Wheeler MJ, de Graaf BH, Hadjiosif N, Perry RM, Poulter NS, Osman K, Vatovec S, Harper A, Franklin FC, Franklin-Tong VE (2009) Identification of the pollen self-incompatibility determinant in Papaver rhoeas. Nature (Lond) 459:992-995

Wheeler MJ, Vatovec S, Franklin-Tong VE (2010) The pollen S-determinant in Papaver: comparisons with known plant receptors and protein ligand partners. J Exp Bot 6:2015-2025

Yao CK, Lin YQ, Ly CV, Ohyama T, Haueter CM, Moiseenkova-Bell VY, Wensel TG, Bellen HJ (2009) A synaptic vesicle-associated $\mathrm{Ca}^{2+}$ channel promotes endocytosis and couples exocytosis to endocytosis. Cell 138:947-960

Zhang DP, Ghislain M, Huamán Z, Golmirzaie A, Hijmans RJ (1998) RAPD variation in sweet potato [Ipomoea batatas (L.) Lam] cultivars from South America and Papua New Guinea. Genet Res Crop Evol 45:271-277 